\title{
Özel Gereksinimli Bireylerin Sosyal Kabullerini Sağlamada Normal Gelişim Gösteren Öğrencilere Sunulan Kaynaştırmaya Hazırlık Etkinliklerinin Etkisi
}

\author{
The Effects of Inclusion Preparation Activities on Providing Social Acceptance of \\ Typical Students for Students with Special Needs
}

\author{
Özlem Özkan Yaşaran - Doç. Dr. Sema Batu - Doç. Dr. Arzu Özen
}

\section{Öz}

Bu araştırmanın amact, özel gereksinimli bireylerin sosyal kabullerini sağlamada normal gelişim gösteren öğrencilere sunulan kaynaştırmaya hazırlik etkinliklerinin etkisini belirlemektir. Araştırma, Eskişehir ilindeki iki ilköğretim okulunun 3., 4. ve 5. sinı öğrencileri ile yürütülmüştür. Araştırmaya deney grubundan 24, kontrol grubundan 24 olmak üzere toplam 48 öğrenci katılmıştır. Araştırmanın deney grubunda yer alan ögrrencilerle araştırmacılar tarafindan hazırlanan kaynaştırmaya hazırlik etkinlikleri uygulanmıştır. Uygulama 10 kaynaştırmaya hazırlı etkinliğinden oluşmaktadır. Araştırmada normal gelişim gösteren öğrencilerin kaynaştırmaya hazırlik etkinliklerinin uygulanması öncesi ve sonrası sosyal kabul düzeylerinin belirlenmesine yönelik ön-test-son-test kontrol gruplu deneysel model kullanılmıştır. Araştırma verileri "Sosyal Kabul Ölçeği" ile toplanmış, elde edilen veriler SPSS 15.00 paket programı ile değerlendirilmiştir. Araştırma sonucunda elde edilen bulgular, normal gelişim gösteren öğrencilerle gerçekleştirilen kaynaştırmaya hazırlık etkinliklerinin, özel gereksinimli bireylere yönelik sosyal kabulü artırmada etkili olduğunu göstermiştir.

Anahtar Sözcükler: Özel Gereksinimli Bireyler, Kaynaştırma, Kaynaştırmaya Hazırlı Etkinlikleri, Sosyal Kabul

\begin{abstract}
The purpose of the present study was to examine the effects of inclusion preparation activities conducted with normally developing peers on providing social acceptance of students with special needs. The study was conducted with the $3^{\text {rd }}, 4^{\text {th }}$, and $5^{\text {th }}$ grade students of two primary schools in Eskişehir. 24 students within the experiment group and 24 students within the control group were participated in the study with a total of 48 students. Inclusion preparation activities which were developed by the authors were conducted with the students of the experimental group. The inclusion preparation activities used in the study were consisted of 10 different activities. The study was conducted with an experimental design with pre-post test control gro$u$. The pre-post tests were used in order to determine the social acceptance of normally developing peers towards individuals with exceptionalities before and after the inclusion preparation activities were conducted. The data of the study were collected via "The Social Acceptance Scale" and analyzed via SPSS 15.00 program. The results of the study revealed that the inclusion preparation activities were effective on increasing the social acceptance of normally developing individuals towards their peers with special needs.
\end{abstract}

Keywords: Individuals with Special Needs, Inclusion, Inclusion Preparation Activities, Social Acceptance

Özlem Özkan Yaşaran, Anadolu Ünv. Eğitim Bilimleri Ens. Özle Eğitim Böl. Zihin Engelliler ABD yüksek lisans mezunu, ozikan82@hotmail.com Doç. Dr. Sema Batu, Anadolu Üniversitesi Engelliler Araştırma Entitüsü, esbatu@anadolu.edu.tr

Doç. Dr. Arzu Özen, Anadolu Üniversitesi Engelliler Araştırma Entitüsü, aozen@anadolu.edu.tr 


\section{Giriş}

Özel gereksinimli bireylerin toplumun bir üyesi olarak yaşayabilmeleri için normal gelişim gösteren bireyler gibi eğitimde firsat eşitliğinden yararlanmaları gereklidir. Son yıllarda değişen okul politikaları ve yasalarla en az kısıtlayıcı ortamın desteklenmesi ve özel gereksinimli bireylerin akranlarıyla aynı ortamlarda eğitim görmeleri, diğer bir deyişle kaynaştırılmaları fikri kabul edilmektedir. Kaynaştırma uygulaması bu hedefi karşılamak için uygun bir araç olma özelliği gösterebilmektedir (Turhan, 2007, s.17). Özel gereksinimli bireylerin akranları ile birlikte olup, eğitsel ihtiyaçlarını bir takım ek düzenlemelerle karşılayabildikleri ortamlar kaynaştırma sınıflarıdır. Sucuoğlu ve Kargın (2006, s.29) kaynaştırmayı; "Özel gereksinimli öğrencinin genel eğitim okullarında normal gelişim gösteren akranlarıly birlikte, gerektiğinde kendisine ve sınıf öğretmenine destek hizmetler sağlamak suretiyle öğretim görmesidir.” şeklinde tanımlamışlardır.

Kaynaştırma uygulamalarının başarıya ulaşabilmesi bir takım unsurların varlığına bağlıdır. Kaynaştırma uygulamalarında en önemli etken kaynaştırma ekibidir. Ekipte yer alan okul yöneticileri, sınıf öğretmeni, özel eğitim öğretmeni, akran öğrenciler, kaynaştırma öğrencisinin ailesi ve diğer personelin her birinin uygulamalar sırasinda belirli görev ve sorumlulukları vardır (Batu ve Kırcaali-İftar, 2006, s.23; Diler, 1998, s.157-162). Ekip içerisinde önemli bir yeri olan normal gelişim gösteren çocukların özel gereksinimli öğrencilerle uygun etkileșimler kurmaları, kaynaştırma uygulamalarının önemli hedeflerinden biridir. Bu nedenle normal gelişim gösteren akranların, özel gereksinimli bireylere yönelik tutumlarında olumlu değişiklikler yaratmanın kaynaştırmanın başarısını etkileyeceği düşünülmektedir.

Normal gelişim gösteren akranlar özel gereksinimli bireylerle karşılaştıklarında çoğunlukla onların farklılıkları konusunda net bilgilere sahip olmamaktadırlar. Yetersizlik ile ilgili bilgi eksikleri, normal gelişim gösteren öğrencilerin özel gereksinimli akranlarına nasıl yaklaşacaklarını ve nasıl davranacaklarını bilememelerine, bunun sonucu olarak da özel gereksinimli çocuklardan uzak durmalarına neden olmaktadır (Batu, Çolak ve Odluyurt, 2012). Pek çok özel gereksinimli öğrenci kaynaştırmaya hazırlık etkinlikleri gerçekleştirilmeden kaynaştırma ortamlarına yerleştirildiğinde, akranları tarafından reddedilmekte ve çeşitli sorunlar yaşamaktadırlar. Normal gelişim gösteren akranların yanı sıra sınıf öğretmenleri de, özel gereksinimli öğrencilerin akranları tarafından sosyal kabullerini sağlayabilmek için ne yapacaklarını bilememekte ve farkında olmadan kendileri de özel gereksinimli öğrencilerini reddedebilmektedirler (Batu, 2008, s.91-106). Özel gereksinimli bireylerin sosyal kabul görmemesi, zaten düşük olan benlik saygısının daha da düşmesine ve yetersizlik duygusuna yol açmaktadır. Ayrıca, sosyal kabul görmeyen özel gereksinimli bireyler problem davranışlar gösterebilmekte ve sosyal ilişkilerden kaçabilmektedirler (Civelek, 1990, s.100).

Kaynaştırmaya hazırlık etkinlikleri, özel gereksinimli öğrencilerin normal gelişim gösteren akranları tarafindan kabul görmelerinde ve önyargılardan kaynaklanan olumsuz tutumların değişmesinde önemli rol oynamaktadır. Bu nedenle, okul çağındaki normal gelişim gösteren öğrencilere kaynaştırma uygulamaları öncesinde kaynaştırmaya hazırlık etkinlikleri sunulması önemlidir (Aktaş, 2001, s.87-91; Civelek, 1990, s.100; Şahbaz, 2007, s.199-208; Tekin, 1994, s.84-89). Bu etkinlikler kapsamında normal gelişim gösteren akranlarla yapılacak bilgilendirme, canlandırma ve yaşantıya dayalı çalışmaların, özel gereksinimli bireylere yönelik olumlu tutumlar gelişmesine ve bu bireylerin sosyal olarak kabul edilme düzeylerinin artmasına katkıda bulunacağı düşünülmektedir. Ayrıca, özel gereksinimli öğrenci akranları tarafından sosyal olarak kabul gördügünde, kendisine yönelik yapılan eğitsel düzenlemelerden daha olumlu sonuçlar alınacaktır (Manetti, Schneider ve Siperstein 2001, s.282-285). Bu gereksinimden yola çıkarak Donaldson (1980, s.504-514) yaptığı çalışmada, özel gereksinimli bireylere yönelik sosyal kabulün artırılmasında kullanılabilecek farklı uygulamalardan söz etmiştir. Bu uygulamaları, (a) özel gereksinimli bireylerle doğrudan iletişim kurma, (b) özel gereksinim hakkında bilgilendirme (tanımı, nedeni, sınıflandırılması, eğitimleri ve yaşadıkları yetersizlikler, vb.) çalışmaları yapma, (c) özel gereksinimli bireyler konusunda topluma etkileyici ve inandırıcı mesajlar verme, (d) özel gereksinimli bireylere karşı olumsuz tutumlara neden olan önyargıları analiz etme, (e) farklı yetersizliklere sahip bireylerin yaşadıkları yetersizlikleri anlamaya yönelik canlandırma çalışmaları yapma ve (f) grup tartışmaları şeklinde sıralamıştır. Aynı şekilde Ibrahim (1982, s.29-36) de özel gereksinimli bireylere yönelik sosyal kabul düzeyinin artırılmasına yönelik yapılacak çalışmalarda tek bir uygulama tekniği yerine, farklı tekniklerin bir arada kullanıldığı çalışmaları önermektedir. 
Alanyazında, özel gereksinimli bireylerle ilgili bilgilendirme, canlandırma, tartışma ve etkileşim yöntemlerinin kullanıldığ $\mathrm{Bu}$ çalışmalara bakıldığında, yukarıda Donaldsan’ın (1980) da ifade ettiği kaynaştırmaya hazırlık etkinlikleri iki farklı amaçla kullanılmıştır. Bu amaçlardan biri özel gereksinimli bireylere yönelik tutumların değiştirilmesi, diğeri ise sosyal kabul düzeylerinin olumlu yönde değiştirilmesidir. Yapılan çalışmaların bulguları normal gelişim gösteren akranların hem sosyal kabullerinin hem de tutumlarının olumlu yönde değiştiğini göstermiştir (Anderson, 1992; Aral ve Dikici, 1998, Leyser, Cumblad ve Strikman, 1986; Şahbaz, 2004, Vuran, 2005; Turhan, 2007). Bu nedenle, bu çalışmada benzer kaynaştırmaya hazırlık etkinliklerinin kullanıldığı her iki amaca yönelik araştırma örneklerine de yer verilmiştir. Örneğin Leyser, Cumblad ve Strikman (1986) araștırmalarında, özel gereksinimli bireylere yönelik tutumları değiştirmeyi hedeflemişlerdir. Bu amaçla araştırmacılar, ilkokul beşinci sınıfa devam etmekte olan 232 öğrenciye geliştirdikleri bir programı uygulamışlardır. Program; (a) görme, işitme ve zihinsel yetersizlikle ilgili tıbbi sorunların anlatıldığı bilgileri, (b) yetersizliğin günlük yaşama getirdiği kısttlamaları, (c) öğrenme ve okula uyumla ilgili yaşanan güçlükler gibi konulara ilişkin bilgileri ve (d) özel gereksinimli bireylerin bağımsız yaşamaları için gerekli toplumsal düzenlemelere ilişkin bilgileri içermiştir. Program, özel gereksinimli bireylere yönelik bilgilendirme çalışmalarının yanı sıra, yaşantı sağlama, özel gereksinimli konuşmacılar davet etme ve grup tartışması gibi pek çok ögeyi de içermiştir. Çalışmanın sonuçları, özel gereksinimli bireylere yönelik tutumların olumlu yönde değiştirilmesinde farklı etkinliklerden oluşan programın etkili olduğunu göstermiştir.

Anderson (1992) ise yaptığ sinimli bireylere yönelik tutumları değiştirmede üç farklı programın etkililiğini belirlemeye çalışmıştır. Çalışmaya ilkokul üçüncü sınıf öğrencileri katılmıştır. Öğrenciler üç gruba ayrılmıştır. Birinci gruba bilgilendirme çalışmaları yapılmıştır. İkinci gruptaki öğrencilere yetersizlik gruplarıyla ilgili video gösterileri yapılmıştır. Üçüncü gruptaki öğrencilere bilgilendirme ve video gösterimi birlikte sunulmuştur. Yap1lan üç uygulamanın sonunda da hazırlanan programların özel gereksinimli bireylere yönelik tutumları ve bilgileri değiştirmede etkili olduğu görülmüştür.
McGowan (1999), normal gelişim gösteren akranların özel gereksinimli bireylere karşı tutumlarını canlandırma tekniği kullanarak değiştirmeyi amaçlayan bir araştırma yapmıştır. Araştırmada yüksekokula devam eden 37 öğrenci yer almıştır. Araştırmanın deney grubundaki öğrencilerle tekerlekli sandalye veya koltuk değneğini kullanarak verilen görevleri yerine getirmeyi içeren canlandırma etkinlikleri gerçekleştirilmiştir. Uygulama öncesinde ve sonrasında öğrencilere yetersizliği olan bireylere yönelik tutum ölçeği uygulanmıștır. Araştırmadan elde edilen bulgular canlandırma etkinliklerine katılan öğrencilerin özel gereksinimli bireylere yönelik tutumlarının olumlu yönde değiştiğini göstermiştir.

Türkiye'de de konuyla ilgili pek çok çalışma yapıldığg görülmektedir. Aral ve Dikici (1998,s.49-54), Şahbaz (2004, s.82-92), Vuran (2005, s.217-235) ve Turhan (2007, s.46-65) normal gelişim gösteren akranların özel gereksinimli bireylere yönelik tutumlarını ve sosyal kabullerini araştırmışlar ve tutumların genellikle olumsuz ve sosyal kabul düzeyinin de düşük olduğunu belirlemişlerdir. Ayrıca, bilgilendirme, canlandırma ve kendini özel gereksinimli bireylerin yerine koyarak yaşantı sağlama gibi, kaynaştırmaya hazırlık etkinliklerinin etkililiğini belirlemeyi amaçlayan araştırmalar, bu tür etkinliklerin, normal gelişim gösteren öğrencilerin özel gereksinimli bireylere yönelik olumsuz tutumlarının değiștirilmesinde, sosyal kabulün ve etkileşimin artırılmasında etkili olduğunu göstermektedir (Aktaş, 2001, s.87-91; Civelek, 1990, s.100; Şahbaz, 2007, s.199-208; Tekin, 1994, s.84-89).

Civelek (1990) eğitilebilir zihin yetersizliği olan çocukların sosyal kabul görmelerinde normal gelişim gösteren çocukların bilgilendirilmelerinin ve iki grubun resim iş ve beden eğitimi derslerinde kaynaştırılmalarının etkilerini araştırmıştır. Özel eğitim sınıfında öğrenim gören altı zihin yetersizliği olan öğrenciden üçü resim iş ve beden eğitimi derslerinde dördüncü sınıfa devam eden öğrencilerle kaynaştırılmış, diğer üçü ise aynı derslerde normal gelişim gösteren akranlarıyla kaynaştırılmıs aynı zamanda da normal gelişim gösteren akranlara bilgilendirme yapılmıştır. Ayrıca bilgilendirme programları video gösterimiyle de desteklenmiştir. Öğrencilerin uygulama öncesindeki ve sonrasındaki tutumları Siperstein (1980) tarafından geliştirilen ve Civelek tarafından Türkçeye uyarlanan "Sosyal Kabul Ölçeği" (SKÖ) ile değerlendirilmiştir. Araştırmanın sonuçları, bilgilendirme ve kaynaştırmanın birlikte yapıldığı grupta yer alan akranların zihin yetersizliği olan akranlarına daha fazla sosyal kabul gösterdiklerini ortaya koymuştur. 
Tekin (1994) bilgilendirme programlarının yetersizliğe sahip bireylerin sosyal kabulü üzerindeki etkilerini araştırmıştır. Uygulama öncesinde ve sonrasında katılımcıların sosyal kabul düzeylerini belirlemek için SKÖ kullanılmıştır. Çalışmada 4. sınıf öğrencilerine dokuz hafta süreyle geleneksel, yönlendirici ve yönlendirici olmayan akran tartışmasını ön plana çıkaran yöntemle yetersizliğe sahip bireyler hakkında bilgi sunulmaya çalışılmıştır. Araştırmanın sonuçları yönlendirici ve yönlendirici olmayan grup çalışmalarının her ikisinin de benzer biçimde tutum değişikliğine yol açtığına işaret etmiştir.

Aktaş (2001) bedensel yetersizliği olan bireyler hakkında hazırlanan "Bilişsel ve Duyuşsal Temelli Eklektik Program"”n ilköğretim ikinci kademe öğrencilerinin bedensel yetersizliği olan yaşıtlarına ilişkin sosyal kabulleri ve bedensel yetersizliği olan bireylere yönelik tutumları üzerindeki etkisini araştırmıştır. Araştırmada veri toplama aracı olarak SKÖ ve "Yetersizlikten Etkilenmiş Bireylere Yönelik Tutum Ölçeği" kullanılmıştır. Çalışmanın deney grubunda yer alan ilköğretim 6., 7. ve 8. sinıflardan seçilen öğrencilere haftada iki gün 90 dakika süren yedi oturumdan oluşan bir program uygulanmıştır. Araştırma sonuçları uygulanan programın normal gelişim gösteren akranlarının bedensel yetersizliği olan bireylerin yaşantılarına yönelik sosyal kabullerini arttırmada ve bedensel yetersizliği olan bireylere yönelik tutumlarını değiştirmede etkili olduğunu göstermiştir.

Şahbaz (2007) ise normal gelişim gösteren öğrencilerin kaynaştırma sınıflarına devam eden özel gereksinimli öğrenciler hakkında bilgilendirilmelerinin özel gereksinimli bireylerin sosyal kabul düzeylerine etkisini araştırmıştır. Araştırmada “Kimdir Bu?" tekniği kullanılarak sekiz zihinsel yetersizliğe sahip öğrencinin öğrenim gördüğü altı şubede bulunan 186 normal gelişim gösteren öğrencinin özel gereksinimli akranlarına yönelik kabul düzeyleri belirlenmiş ve uygulanan bilgilendirme programının etkisi incelenmiştir. Araştırmanın sonucunda, özel gereksinimli öğrencilerin toplumsal açıdan olumlu özellikleri olduğunu söyleyen öğrenci sayısında bir artış, olumsuz özellikleri olduğunu söyleyen öğrenci sayısında ise azalma olduğu bulunmuştur. Ayrıca, Eratay ve Sazak Pınar (2006) yılında kaynaştırma sınıflarında bulunan zihinsel yetersizliği olan öğrencilerin okul ortamındaki arkadaşlık ilişkilerini incelemek ama- clyla beş zihin yetersizliği olan, 30 normal gelişim gösteren öğrenci ve beş sınıf öğretmeniyle bir çalışma gerçekleştirmişlerdir. Çalışmada Şahbaz (2007) 'in çalışmasında olduğu gibi "Kimdir Bu" tekniği ve buna ek olarak "Sosyometri" tekniği kullanılarak veriler toplanmıştır. Çalışma sonucunda çalışılan sınıflarda bulunan zihinsel yetersizliği olan öğrencilerin yalnız kalan arkadaşları tarafından oyun ve sıra arkadaşı olarak tercih edilmeyen ve dışlanan öğrenciler oldukları görülmüştür.

Türkçe alanyazında, özel gereksinimli öğrencilerin normal gelişim gösteren akranları tarafından sosyal kabulünü artırmaya yönelik yukarıda belirtilen çalışmalar olmakla birlikte, konuya ilişkin araştırma gereksinimi halen devam etmektedir. Alanyazında yer alan çalışmalar incelendiğinde, Civelek (1990) tarafından yapılan çalışmanın zihin yetersizliği olan bireylerin sosyal kabulüne, Aktaş (2001, s.87-91) tarafından yapılan çalışmanın ise bedensel yetersizliği olan bireylerin sosyal kabulüne yönelik olduğu görülmektedir. Tekin (1994, s.10) ve Şahbaz (2007, s.199208) araştırmalarında farklı yetersizlik türlerine sahip öğrencilerin sosyal kabulüne yönelik programlar uygulamışlardır. Şahbaz (2007, s.199-208) yalnızca bilgilendirme programının etkililiğini sınarken, Tekin (1994, s.69) tarafından yapılan çalışmada ağırlıklı olarak bilgilendirme, tartışma ve özel gereksinimli bireylerle yaşantı sağlama gibi uygulamaların yapıldığı görülmektedir.

$\mathrm{Bu}$ çalışmada ise, alanyazında yer alan çalışmalardan farklı olarak tek bir yetersizlik türü yerine farklı yetersizlik türlerine yönelik etkinliklerin yer alması ve farklı yetersizlik türlerine ilişkin bilgi verme, yetersizlik durumuyla ilgili canlandirma yapma ve grup tartışması gibi farklı uygulamaları bir arada içeren özgün bir etkinlik uygulanması nedeniyle alanyazına farklı bir boyutta katkı getireceği düşünülmektedir. Araştırma konusu bu gereksinimden hareketle belirlenmiştir. Bu araştırmanın amacı, özel gereksinimli bireylerin sosyal kabullerini sağlamada normal gelişim gösteren öğrencilere sunulan kaynaştırmaya hazırlık etkinliklerinin etkisini belirlemektir. Bu amaç kapsamında kaynaştırmaya hazırlık etkinliklerinin uygulandığı deney grubunda yer alan öğrencilerin, SKÖ son-test puanları, uygulamaya katılmayan kontrol grubunda yer alan öğrencilerin son-test puanlarından farklı olup olmadığı sınanmıştır. 
$\mathrm{Bu}$ amaç doğrultusunda aşağıdaki hipotezler kurulmuştur:

Ho: Kaynaştırmaya hazırlık etkinliklerinin uygulandığı deney grubunda yer alan öğrencilerin, SKÖ son-test puanları, uygulamaya katılmayan kontrol grubunda yer alan öğrencilerin son-test puanlarından farksızdır.

H1: Kaynaştırmaya hazırlık etkinliklerinin uygulandığ deney grubunda yer alan öğrencilerin, SKÖ son-test puanları, uygulamaya katılmayan kontrol grubunda yer alan öğrencilerin son-test puanlarından farklidır.

Ayrıca çalışmada kaynaştırmaya hazırlık etkinliklerinin uygulandığ grupta yer alan öğrencilerin annelerinin, çocuklarının kaynaştırmaya hazırlık etkinlikleri uygulamasına katılımı konusundaki düşünceleri incelenmiştir.

\section{Yöntem}

\section{Araştırma Modeli}

$\mathrm{Bu}$ araştırma, normal gelişim gösteren öğrencilerle gerçekleştirilen kaynaştırmaya hazırlık etkinliklerinin, özel gereksinimli bireylerin sosyal kabullerini sağlamadaki etkisini belirlemeyi amaçlayan ön-testson-test kontrol gruplu deneysel bir çalışmadır.

Ön-test-son-test kontrol gruplu bu çalışmanın bağımsız değişkeni, normal gelişim gösteren öğrencilerle gerçekleştirilen kaynaştırmaya hazırlık etkinlikleridir. Kaynaştırmaya hazırlık etkinlikleri toplam 10 etkinlikten oluşmaktadır. Etkinlikler farklı yetersizlik türlerine ilişkin bilgi verme, yetersizlik durumuyla ilgili canlandırma yapma ve grup tartışması çalışmalarını kapsamaktadır. Araştırmanın bağımlı değişkeni, normal gelişim gösteren öğrencilerin, özel gereksinimli bireyleri sosyal kabul düzeyleridir.

\section{Çalışma Grubu}

Eskişehir Merkez İlçede belirlenen eğitim bölgesinde 10 ilköğretim okulu bulunmaktadır. Çalışma grubunu, bu okullar içerisinden benzeşik örnekleme dayalı olarak seçilen iki ilköğretim okulunun ilk kademesinin 3., 4. ve 5. sinıflarında bulunan öğrenciler oluşturmaktadır. Benzeşik örneklemede araştırmacı amaçlı olarak bir alt grubu oluşturan belirleyici özellikleri seçmeli ve bu özelliklere uyan bireyleri ya da ortamları bulmalıdır (Büyüköztürk, Kılıç-Çakmak, Akgün,
Karadeniz ve Demirel, 2008; Gay, Mills ve Airasian, 2006). Bu amaçla çalışmanın deney ve kontrol grubunda yer alacak öğrencilerin sosyal kabul düzeylerini etkileyebilecek sosyo-ekonomik düzeyleri, başarı durumları, özel gereksinimli bireylerle yaşantılarının olup olmaması ve sınıf öğretmenlerinin özel gereksinimli bireylerle çalışma deneyimleri olup olmaması gibi belirli değişkenlerin olabileceği düşünülmüştür. Bu gerekçeyle çalışmaya katılacak deneklerin benzer sosyo ekonomik koşullara sahip oldukları varsayılarak aynı eğitim bölgesinde yer alan iki ilköğretim okulu belirlenmiştir. Araştırmaya katılan öğrencilerin demografik bilgilerini ve özel gereksinimli bireylerle yaşantılarının olup olmadığını belirlemek amacıyla araştırmacılar tarafından "Öğrenci Bilgi Formu" hazırlanmıştır. Form her iki gruba da uygulanmıştır. Her iki grupta yer alan deneklerin bilgi formlarından elde edilen bilgiler değerlendirilmiş ve gruplar arasında anlamlı bir farklılığın olmadığ 1 görülmüştür. Araştırmadaki diğer bir değişken ise, deney ve kontrol grubunda yer alan öğrencilerin sinıf öğretmenlerinin özel gereksinimli bireylerle ilgili aldıkları eğitimin içeriği ve çalışma deneyimleridir. Bu amaçla da deney ve kontrol grubunda yer alan deneklerin sinıf ögretmenlerine araştırmacılar tarafından hazırlanan "Öğretmen Bilgi Formu" uygulanmıştır. Her iki grupta yer alan sınıf öğretmenlerinin bilgi formlarından elde edilen veriler değerlendirilmiş ve öğretmenler arasında bu değişkenler arasında anlamlı bir farklılığın olmadığı görülmüştür. Çalışmada 3., 4. ve 5. sınıf öğrencilerinin yer almasının nedeni olarak öğrencilerin okuduklarını anlama, bulmaca çözme, kendini başkasının yerine koyma, tartışma gibi önkoşul becerileri karşılar düzeyde olmalarıdır.

Çalışmada bu değişkenlerin dişında deney ve kontrol gruplarının belirlenmesi için öncelikle bu sınıflarda bulunan öğrencilere Siperstein (1980) tarafından geliştirilen ve Civelek (1990) tarafından Türkçeye uyarlanan "Sosyal Kabul Ölçeği" (SKÖ) uygulanmıştır. Öğrencilerin SKÖ’den aldığı ön-test puanlarının ortalaması hesaplanarak sosyal kabul düzeyi en düşük olan iki sınıf belirlenmiştir. Bu sınıflar arasından yansız atama yoluyla kura çekilerek deney ve kontrol grupları oluşturulmuştur.

Araştırmada deney ve kontrol gruplarında yer alan deneklerin geliştirilen SKÖ ön-test puan ortalamaları deney grubunun 71.83, kontrol grubunun ise 72.91'tir. $\mathrm{Bu}$ açıdan da hem deney hem kontrol grubu arasında anlamlı bir farklılığın olmadığı belirlenmiștir. 


\section{Deney Grubu}

Araştırmanın deney grubu ilköğretim üçüncü sınıfa devam eden 13 erkek ve $11 \mathrm{k}$ z olmak üzere toplam 24 öğrenciden oluşmaktadır. Bu öğrencilerle ön-testson-test ve araştırmacı tarafından hazırlanan kaynaştırmaya hazırlık etkinlikleri uygulaması yapılmıştır.

\section{Kontrol Grubu}

Araştırmanın kontrol grubu ilköğretim üçüncü sınıfa devam eden 11 erkek ve $13 \mathrm{kız}$ olmak üzere toplam 24 öğrenciden oluşmaktadır. Bu öğrencilere ön-testson-test uygulaması yapılmış ancak, kaynaştırmaya hazırlık etkinliklerinin uygulaması yapılmamıştır.

\section{Veri Toplama Araçları}

Bu araştırmada, akranlarının özel gereksinimli bireylere yönelik sosyal kabul düzeylerini belirlemek amacıyla SKÖ, öğrencilerin demografik bilgilerinin elde edilmesi amacıyla birinci araştırmacı tarafından hazırlanan "Öğrenci Bilgi Formu" kullanılmıştır. Araştırmada ayrıca, öğretmenlerin deneyim ve eğitim bilgilerinin elde edilmesi amacıyla "Öğretmen Bilgi Formu”, araştırmanın sosyal geçerliliğini belirlemek amacıyla "Sosyal Geçerlilik Veri Toplama Aracı" ve uygulama güvenirliğini belirlemek üzere "Uygulama Güvenirliği Veri Formu" kullanılmıştır.

SKÖ, Siperstein (1980) tarafından tutumların bileşenleri arasında yer alan davranışsal boyutu ölçmek amacıyla geliştirilen bir ölçektir (Social Acceptance Scale, Siperstein 1980, Akt. Civelek 1990: s.45). SKÖ 22 maddeden oluşmaktadır. Ölçekte yer alan maddelere verilen tepkiler "Evet", "Sanırım Evet", "Ne Evet Ne Hayır", "Sanırım Hayır" ve "Hayır" șeklinde derecelendirilmiştir. Ölçeğin puanlanmasında Evet (5) puan, Sanırım Evet (4) puan, Ne Evet Ne Hayır (3) puan, Sanırım Hayır (2) puan ve Hayır (1) puan almaktadır. Ölçekten alınabilecek en düşük puan 22 ve en yüksek puan 110'dur. Yüksek puanlar özel gereksinimli bireylere yönelik sosyal kabul düzeyinin yüksek olduğunu göstermektedir. Ölçekte maddeler olumlu kökle ifade edildiğinden, ölçekten alınan puanın yüksekliği özel gereksinimli öğrencinin normal gelişim gösteren akranları arasındaki sosyal kabulün de yüksek olduğu şeklinde yorumlanmaktadır. Ölçeğin, Türkçe’ye kazandırılması Civelek (1990) tarafından yapılmıştır. Ölçek önce 5 kişi tarafından Türkçe’ ye çevrilmiş daha sonra uzman grubunun görüşleri dikkate alınarak düzenlemeler yapılmıștır. Aynı zamanda uzman grubundan testin sosyal kabulü ölçtügüne ilişkin alınan geri bildirimlere dayalı olarak testin kapsam geçerliğinin olduğu düşünülmüştür. Bu çalışmadan sonra ölçek, 83 yetersizliği olmayan öğrenciye bir ay arayla uygulanmış ve güvenirlik katsayısı 0.83 olarak bulunmuştur. Yapilan bu çalışmalar sonucunda Civelek (1990) aracın geçerli ve güvenilir bir ölçek olduğu sonucuna varmıştır.

Öğrenci Bilgi Formu, araştırmada yer alan öğrencilere ilişkin bazı demografik bilgileri ve özel gereksinimli bireylerle yaşantılarının olup olmadığını belirlemek amacıyla araştırmacılar tarafından geliştirilmiştir. Ayrica, bu form deney ve kontrol grubunda yer alan öğrencilerin özel gereksinimli bireyler hakkında yaşantıları ve bilgileri açısından eş düzeyde olmalarını sağlamak üzere kullanılmıştır. Form iki bölümden oluşmaktadır. Birinci bölümde, öğrencilerin kimlik bilgileri ve demografik bilgiler, ikinci bölümde ise, özel gereksinimli bireylerle daha önce yaşantılarının olup olmadığını belirlemeye yönelik üç soru yer almıştır. Öğrencilerden, "Öğrenci Bilgi Formu”nu öntest uygulaması öncesinde doldurmaları istenmiştir.

Öğretmen Bilgi Formu, araştırmada deney ve kontrol grubundaki öğrencilerin sınıf öğretmenlerine uygulanmıştır. Form araştırmacılar tarafından geliştirilmiştir. "Öğretmen Bilgi Formu”nda öğretmenlerin eğitim, deneyim ve özel gereksinimli bireylerle yaşantılarının olup olmadığını belirlemeye yönelik 3 soru yer almaktadır. "Öğretmen Bilgi Formu”, çalışma öncesinde öğretmenler tarafından doldurularak araştırmacılara teslim edilmiştir. Formdan elde edilen bilgiler, çalışmanın deney ve kontrol grubunda yer alan öğrencilerin öğretmenlerinin eğitim, deneyim ve özel gereksinimli bireylerle yaşantıları açısından eş düzeyde olmalarını sağlamak amacıyla kullanılmıştır.

Sosyal Geçerlik Veri Toplama Aracı, araştırmacılar tarafından geliştirilmiştir. Sosyal Geçerlik, çalışmayla ilişkili kişilerin çalışmanın önemine, etkililiğine, uygunluğuna ve/veya yaratmış olduğu hoşnutluk düzeyini belirlemeye ilişkin yapılan değerlendirmelerdir (Kennedy, 2005; Kurt, 2012). Çalışmada bu amaçla hazırlanan "Sosyal Geçerlik Veri Toplama Aracı" altı maddeden oluşmaktadır. Her bir madde çalışmaya katılan çocukların annelerinin çocuklarına ilişkin gözlemlerini kapsamaktadır. Annelerden bu maddeleri okuyup yanıtlarını "Evet" ya da "Hayır" olarak işaretlemeleri istenmiştir. Annelere formu doldurmadan önce çocuklarıly gerçekleştirilen etkinlikler ve doldurmaları gereken form ile ilgili bilgi verilmiştir. Annelere yöneltilen ifadeler; (a) Yapılan çalışmanın 
çocuğum için yararlı olduğunu düşünüyorum, (b) Çocuğumun evde özel gereksinimli bireylerden bahsetmeye başladığını fark ettim, (c) Çocuğumun özel gereksinimli bireyleri daha iyi anlayabileceğini düşünüyorum, (d) Çocuğumun özel gereksinimli çocuklarla da arkadaşlık yapmaya başlayacağını düşünüyorum, (e) Çocuğumun özel gereksinimli kişilere nasıl yardım edebileceğini öğrendiğini düşünüyorum ve (f) Çalışmayla ilgili bir fikrim yok şeklindedir. "Sosyal Geçerlilik Veri Toplama Aracı" deney grubunda yer alan öğrencilerin annelerine uygulama tamamlandıktan bir hafta sonra kapalı zarf içerisinde gönderilerek uygulanmıştır. Deney grubundaki 24 öğrencinin annelerinden yalnızca bir anne formu doldurarak geri göndermemiştir. Bu nedenle bu çalışmada 23 anneden sosyal geçerlik verisi toplanmıştır.

Uygulama Güvenirliği Veri Formu, araştırmacılar tarafından araştırmada yer alan bağımsız değişkenin ne derece planlanan şekilde uygulandığını belirlemek üzere geliştirilmiştir. Diğer bir değişle uygulama güvenirliğinde planlanan uygulamanın ne kadar doğru olarak uygulandığına bakılmıştır. Uygulama güvenirliği belirlenirken, uygulamanın sadece temel bileşeninin doğru uygulanıp uygulanmadığı değil, uygulamada yer alan diğer bileșenlerinde doğru uygulanıp uygulanmadığı değerlendirilmektedir. Bu çalışmanın bağımsız değişkeni toplam 10 etkinlikten oluşan "Kaynaştırmaya Hazırlık Etkinlikleridir " Her bir etkinliğin planlanan şekilde uygulanıp uygulanmad1ğını değerlendirmek için ortak bir form geliştirilmiştir. Formda, (a) Etkinlikte kullanılacak materyaller hazırlandı mı? (b) Etkinliğin amacı açıklandı mı? (c) Etkinlik başlamadan önce etkinlikle ilgili bilgilendirme yapıldı mı? (d) Etkinlikle ilgili alıştırmalar yapıldı mı? (e) Katılımcıların uygun davranışları pekiştirildi mi? (f) Etkinlik katılımcılarla birlikte değerlendirildi mi? (g) Etkinlik planlanan sürede uygulandı mı? sorularına yer verilmiştir. Araştırmada uygulama güvenirliği verileri (gözlenen uygun davranış/planlanan uygun davranış X 100) formülü kullanılarak hesaplanmıştır (Erbaş, 2012). Araştırmanın uygulama güvenirliği verileri, üçüncü yazar tarafından yapılmıştır. Uygulama güvenirliği verileri, tüm etkinliklerin en az \%30'una karşılık gelen 4 kaynaştırmaya hazırlık etkinliğinde toplanmıştır. Etkinliklerdeki uygulama güvenirliği hesaplarına bakıldığında \%98 (ranj=\%95$\% 100)$ olduğu görülmektedir.

\section{Kaynaştırmaya Hazırlık Etkinlikleri Materyallerinin Hazırlanması}

Araştırmanın uygulama sürecinde kullanılmak üzere birinci ve ikinci araştırmacı tarafından hazırlanan "Kaynaştırmaya Hazırlık Etkinlikleri" toplam 10 etkinlikten oluşmaktadır. Hazırlanan etkinlikler, ilköğretim okulu ilk kademede okuyan 3., 4. ve 5. s1nıf öğrencilerinin yaş düzeylerine uygun etkinlikleri içermektedir. Bu konuda alanyazında yapılan çalışmalar taranmış, farklı yetersizlik grupları için ne tür uyarlamaların yapıldığ 1 incelenmiştir (Aktaş, 2001; Civelek, 1990; Tekin, 1994).

Araştırmacı tarafından kaynaştırmaya hazırlık etkinlikleri hazırlanmadan önce Milli Eğitim Bakanlığ (MEB) tarafından ilköğretim okulları için hazırlanan grup rehberliği etkinlikleri incelenerek kaynaştırmaya hazırlıkla ilgili olan etkinlikler bu araştırmanın etkinliklerini oluştururken göz önünde bulundurulmuştur. Alanyazın çalışmaları temel alınarak kaynaştırmaya hazırlık etkinlikleri araştırmacılar tarafından özgün olarak hazırlanmıştır. Kaynaştırmaya hazırlık etkinliklerinin öğrencilerin okuma-yazma becerileri, gelişim ve öğrenme düzeyleri de göz önünde bulundurularak uygunluğunu belirlemek amaciyla uzman görüşü alınmıştır. Bu amaçla hazırlanan etkinlikler özel eğitim alanındaki iki uzman tarafından incelenmiştir. Uzmanlardan gelen dönütler doğrultusunda gerekli değişiklikler yapılmış ve etkinliklere son şekli verilmiştir. Etkinlikler; bilgi verme, tartışma ve canlandırma yapma gibi çalışmaları kapsamaktadır.

Bilgi verme ve tartışma etkinliklerinin amacı, normal gelişim gösteren akranların, özel gereksinimli bireylerle ilgili yanlış ya da eksik bilgi sahibi olmalarından kaynaklanan olumsuz tutumları ortadan kaldırmak ya da en aza indirgemektir. Öğrencilerin bireysel farklılıklar ve benzerlikler konusunda bir bakış açısı geliştirmelerini ve özel gereksinimli bireylerle ilgili duygu ve düşüncelerini arkadaşlarıyla bir tartışma ortamında paylaşmalarını sağlama da amaçlar arasındadır. Bilgi verme ve tartışmayı içeren etkinlikler; "Eğrisi Doğrusu; Bulmacada Gizli; Bilelim Bulalım; Seç Bakalım; Bizim Köyümüz" başlıklı etkinliklerdir. Bu etkinliklerden biri örnek olarak Ek-1'de yer almaktadır.

Canlandırma etkinliklerinin amacı, normal gelişim gösteren akranların, özel gereksinimli bireylerin yaşadıkları güçlüklerin farkına varmaları ve canlandırma sirasında farklı yetersizlik türlerindeki bireylerin 
yaşadıkları zorluklar ve sınırlılıklar karşısında duyarlılık kazanmalarını sağlamaktır. Canlandırma çalışmalarını içeren etkinlikler; "Ben Olsaydım; Yaşadım, Gördüm, Anlıyorum; Görmeden Nasıl; Anlat Bakalım; Benim İçin Zor” başlıklı etkinliklerdir.

\section{Ortam}

Araştırmada ön-test uygulamaları, son-test uygulamaları ve deneysel uygulamalar öğrencilerin devam etmekte oldukları sınıf ortamında gerçekleştirilmiştir. Ön-test ve son-test uygulamalarında ve deneysel uygulamalarda sınıfta yalnızca birinci araştırmacı ve denekler bulunmuştur. Araştırmacı tarafından uygulamaların video kaydı alınmıştır. Ayrıca, bazı etkinliklerde öğrencilerin uygulama yaptıkları sırada fotoğrafları da çekilmiştir.

\section{Araç-Gereç}

Çalışmada her bir bilgilendirme, tartışma ve canlandırma etkinliği için uygun araç-gereç kullanılmıştır. Bunlara örnek olarak, farklı yetersizlik türlerini gösteren resimler, farklı yetersizlik türlerinin isimlerinin yer aldığ şılaştıkları güçlükleri ve bu güçlükler karşısında neler yapabileceklerine ilişkin her bir yetersizlik türü ile ilgili üç senaryo, ilgili senaryolarda kullanılan su bardağı, kalemtıraş, kalem, göz bağı, şeffaf dosyalar, ses kayıtları, resim kağıtları, pastel boyalar sıralanabilir.

\section{Deney Süreci}

$\mathrm{Bu}$ bölümde çalışmanın gerçekleştirildiği ortam, öntest uygulaması, uygulama süreci ve son-test uygulaması ile ilgili bilgiler yer almaktadır.

\section{Ön-test Uygulaması}

Ön-test uygulaması deneysel uygulama sürecinden iki hafta önce gerçekleştirilmiştir. Ön-test uygulaması sinıfta bulunan tüm öğrencilere aynı anda uygulanmıştır. Ön-test uygulama süresi ortalama 20 dakika sürmüştür. Öğrencilerin ön-test ve son-testlerini eşleştirebilmek için ölçekleri doldurmadan önce adlarını yazmaları istenmiş; ancak, daha sonra her bir öğrencinin doldurduğu ölçeğe bir numara verilerek veri girişlerinde öğrenciler bu numaralara göre kodlanmıştır.

SKÖ’nün açıklama bölümündeki bilgiler birinci araştırmacı tarafından öğrencilere açıklanmış ve formu nasıl işaretleyecekleri gösterilmiştir. Öğrencilerin bu formları bağımsız olarak işaretlemelerine dikkat edilmiştir. Birinci araştırmacı öğrenciler ölçeği doldururken sinıfta bulunmuştur.

\section{Uygulama Süreci}

Ön-test uygulamasından iki hafta sonra deney grubu ile ilk oturum yapılmış ve ders süresinin ilk 15 dakikasında çalışmanın amacı, çalışma takvimi ve kurallar açıklandıktan sonra birinci etkinliğin uygulaması başlatılmıştır. Araştırmanın deneysel uygulama aşaması toplam 10 etkinlikten oluşmaktadır. $\mathrm{Bu}$ uygulamaları gerçekleştirmek üzere ilgili ilköğretim okulu müdürlüğünden gerekli izinler alınmıştır. Her bir etkinlik 40 dakikalık bir ders saati süresince gerçekleştirilmiştir. Bu etkinlikler arasından "Ben Olsaydım" isimli etkinlik, birden fazla yetersizlik grubu ile ilgili canlandırmaları içerdiği için 80 dakikalık iki ders saatine gereksinim duyulmuştur. Bu şekilde uygulama toplam 11 oturumda gerçekleştirilmiştir. Uygulamalar öğrencilerin akademik derslerinin işlenişini engellememek amacıyla sınıf öğretmeni ile yapılan görüşmeler sonucunda belirlenen müzik, görsel sanatlar, beden eğitimi, rehberlik ve etüt ders saatlerinde gerçekleştirilmiştir. Uygulama 10 gün süresince her gün bir etkinlik uygulaması olacak şekilde gerçekleştirilmiştir.

\section{Son-test Uygulaması}

Uygulama süreci tamamlandıktan iki gün sonra hem deney hem de kontrol grubunda yer alan öğrencilere son-test uygulaması yapılmıştır. Son-test uygulamaları öğrencilerin öğrenim gördükleri sinıfta araştırmacı tarafından ön test uygulamasındaki koşullar içerisinde gerçekleştirilmiştir.

\section{Verilerin Analizi}

Çalışmanın hipotezi kaynaştırmaya hazırlık etkinliklerinin uygulandığı deney grubunda yer alan öğrencilerin SKÖ son-test puanları uygulamaya katılmayan kontrol grubunda yer alan öğrencilerin son-test puanlarından farklı olup olmadığını sinamak üzere hipotezler kurulmuştur:

Ayrıca, deney ve kontrol grubunda yer alan öğrencilere ön-test ve son-test olarak uygulanan SKÖ ile toplanan veriler SPSS 15.00 paket programı ile analiz edilmek üzere bilgisayara girilmiştir. Her iki grupta yer alan ögrencilerin son-test puanları arasında anlamlı bir fark olup olmadığı ve deney grubunda yer alan öğrencilerin uygulama sonrasında SKÖ'den aldıkları puandaki farklılığın anlamlı düzeyde olup olmadığını belirlemek üzere elde edilen puanlara "Tek Yönlü Varyans Analizi (ANOVA)" uygulanmıştır. Verilerin analizinde istatistiksel anlamlılık düzeyi .05 olarak kabul edilmiştir. 
“Tek Yönlü Varyans Analizi (ANOVA)” SPSS 15.00 adlı istatistiksel paket program ile gerçekleştirilmiştir. Bu test ile yapılan hesaba ilişkin anlamlılık düzeyi .05 'ten büyük olması durumunda $\mathrm{H}_{0}$ hipotezi kabul edilirken, bununla birlikte anlamlılık düzeyinin .05 'ten küçük olması durumunda ise $\mathrm{H}_{0}$ hipotezi reddedilip, $\mathrm{H}_{1}$ hipotezi kabul edilmektedir. $\mathrm{H}_{0}$ hipotezinin kabul edilmesi durumunda, kaynaştırmaya hazırlık etkinliklerinin uygulandığı deney grubunda yer alan öğrencilerin SKÖ son-test puanlarının, uygulamaya katılmayan kontrol grubunda yer alan öğrencilerin son-test puanlarından $\% 95$ güvenle (\%5 anlamllık düzeyi ile) istatistiksel olarak anlamlı bir farklılığının olmadığı belirlenmektedir. Bununla birlikte $\mathrm{H}_{0}$ hipotezinin reddedilmesi durumunda, \%95 güvenle (\%5 anlamlılık düzeyi ile) istatistiksel olarak anlamlı bir farklılık belirlenmektedir.

\section{Bulgular}

\section{Normal Gelişim Gösteren Öğrencilerin Özel Ge- reksinimli Akranlarını Sosyal Kabullerini Sağ- lamada Kaynaştırmaya Hazırlık Etkinliklerinin Etkisine İlişkin Ön-Test Son-Test Bulguları}

Kaynaştırmaya hazırlık etkinlikleri sonunda, deney grubundaki öğrencilerin SKÖ'nün ön-test ve sontest oturumundan aldıkları puanlar ile kontrol grubundaki öğrencilerin SKÖ'nün ön-test ve son-test oturumundan aldıkları puanlar arasında fark olup olmadığını belirleyebilmek için “Tek Yönlü Varyans Analizi (ANOVA)" uygulanmıştır. Varyans analizi sınamasına geçmeden önce ölçeğimizin uygulandığ 1 deney ve kontrol grubu öğrencilerinin toplam sayısı $\mathrm{n}=48(\mathrm{n}=24+24048>30)$ olduğu için $\mathrm{n}>30$ normal dağılma gideceği için örneklemimizin normal dağıldığ varsayılmıştır (Ferguson, 1981, s.153; Canküyer ve Aşan, 2005, s.17). Deney ve kontrol grubundaki öğrencilerin, SKÖ aldıkları ön-test ve son-test puanlarının ortalama ve standart sapma değerleri Tablo l'de verilmiştir.

Tablo 1.de görüldüğü gibi, deney grubunda yer alan öğrencilerin uygulama öncesinde SKÖ'den aldıkları puanların ortalaması $\mathrm{X}=71,83$ iken, bu değer uygulama sonrasinda $X=96,92$ olmuştur. Kontrol grubunda yer alan öğrencilerin ise uygulama öncesinde SKÖ'den aldıkları puanların ortalaması $\mathrm{X}=72,92 \mathrm{iken}$, bu değer uygulama sonrasında $\mathrm{X}=72,58$ olmuştur. Buna göre, uygulama sonrasinda deney grubunda yer alan öğrencilerin sosyal kabul düzeyinde bir artışın olduğu, kontrol grubunda yer alan öğrencilerin sosyal kabul düzeyinde ise belirgin bir değişimin olmadığ̣ görülmektedir.

Deney ve kontrol grubunda yer alan öğrencilerin SKÖ puanlarında, uygulama öncesine göre uygulama sonrasında gözlenen değişimlerin anlamlı bir farkl1lık gösterip göstermediğine ilişkin yapılan "Tek Yönlü Varyans Analizi (ANOVA)" sonuçları Tablo 2.'de görülmektedir.

Tablo 1. Sosyal Kabul Ölçeğinden Alınan Ön-Test-Son-Test Ortalama Puan ve Standart Sapma Değerleri

\begin{tabular}{|c|c|c|c|c|c|c|c|c|c|}
\hline \multirow[t]{2}{*}{$\overline{\text { Grup }}$} & \multicolumn{3}{|c|}{ ÖNTEST } & \multicolumn{5}{|c|}{ SONTEST } & \multirow[b]{2}{*}{$\mathrm{S}$} \\
\hline & $\mathrm{N}$ & $\mathrm{X}$ & $\mathrm{S}$ & & $\mathrm{N}$ & & $\mathrm{X}$ & & \\
\hline Deney & 24 & 71,83 & 11,032 & & 24 & & 96,92 & & 7,541 \\
\hline Kontrol & 24 & 72,92 & 8,777 & 24 & & 72,58 & & 11,329 & \\
\hline Toplam & 48 & 72,38 & 9,877 & 48 & & 84,75 & & 15,550 & \\
\hline
\end{tabular}


Tablo 2. Sosyal Kabul Ölçeği Puanlarının Gruplara Göre ANOVA Sonuçları

\begin{tabular}{lllll}
\hline Varyansın & Kareler & & & \\
Kaynă̆1 & Toplamı & sd & F & $p$ \\
\hline Gruplararası & 7105.333 & 1 & 7105.333 & .000 \\
Gruplariçi & 4259.667 & & & \\
& & 46 & 92.601 & \\
Toplam & 11365.000 & & & \\
\hline
\end{tabular}

${ }^{*} \mathrm{p}<0.001$

Tablo 2.deki analiz sonuçları, deney ve kontrol grubunda yer alan öğrencilerin SKÖ puanları arasında anlamlı bir fark olduğunu göstermektedir ( $F(1-$ 46) $=7105.333, p<0,001)$. Başka bir deyişle, kaynaştırmaya hazırlık etkinliklerinin uygulandığı deney grubundaki öğrencilerin sosyal kabul düzeylerinin, kaynaştırma hazırlık etkinliklerinin uygulanmadığı kontrol grubundaki öğrencilerin sosyal kabul düzeylerine göre anlamlı bir şekilde değiştiği görülmektedir.

\section{Sosyal Geçerlilik Bulguları}

Araştırmaya katılan annelerin \% 82'si sosyal geçerlik ölçeğindeki tüm soruları "evet" olarak işaretlemişlerdir. Anneler, yapılan uygulama etkinliklerinin çocukları için yararlı olduğunu düşünmektedirler. Anneler, kaynaştırma etkinliklerinin uygulaması tamamlandıktan sonra, çocuklarının özel gereksinimli bireylerden bahsetmeye başladıklarını, onların yaşadıkları zorlukları daha iyi anladıklarını, onlarla arkadaş olmaya istekli olduklarını düşünmektedirler. Aynı zamanda anneler, çocuklarının özel gereksinimli öğrencilere nasıl yardım edecekleri konusunda fikir sahibi olduklarını düşünmektedirler.

\section{Tartışma ve Öneriler}

$\mathrm{Bu}$ araştırmanın amacı, ilköğretim 3., 4. ve 5. sınıfa devam eden normal gelişim gösteren öğrencilerle gerçekleştirilen kaynaştırmaya hazırlık etkinliklerinin, öğrencilerin özel gereksinimli bireyleri sosyal kabul düzeylerindeki etkisini belirlemektir. Araştırma sonucunda elde edilen bulgular incelendiğinde, başlangıçta deney ve kontrol grubunda yer alan öğrencilerin sosyal kabul düzeylerinin birbirine yakın ve düşük düzeyde olduğu, kaynaştırmaya hazırlık et- kinlikleri uygulaması sonrasında deney grubunda yer alan öğrencilerin sosyal kabul düzeylerinin belirgin şekilde yükseldiği görülmüştür. Kontrol grubunda yer alan öğrencilerin ise sosyal kabul düzeylerinde anlamlı bir değişikliğin olmadığı görülmektedir. Elde edilen bu bulgulara göre kaynaştırmaya hazırlık etkinliklerinin normal gelişim gösteren öğrencilerin özel gereksinimli bireylere yönelik sosyal kabul düzeyini arttırmada etkili olduğu söylenebilir.

Alanyazında özel gereksinimli bireylere yönelik sosyal kabul düzeyinin artırılmasına yönelik farklı uygulama tekniklerinin bir arada kullanımı Donaldson (1980, s.504-514) ve Ibrahim (1982, s.29-36) tarafindan önerilmektedir. Alanyazinda bu uygulama tekniklerinden birinin ya da bir kaçının bir arada kullanıldığı pek çok çalışma planlanmış ve yapilan çalışmaların olumlu etkileri bilimsel olarak kanıtlanmıştır. (Akçamete ve Kargin, 1994, s.13-19; Aktaş, 2001, s.87-91; Krahe ve Altwasser, 2006, s.59-69; Küçüker, 1997; Küçüker ve Richter-Kanık, 1994, s.20-28; Manetti, vd., 2001, s.282-285; Tekin, 1994, s. 84-89). Bu çalışmada da benzer şekilde bilgi verme, canlandırma ve tartışma tekniklerinin bir arada kullanıldığı uygulama etkinlikleri uygulanmış ve araştırmanın sonucunda yapılan uygulamanın etkililiği belirlenmiştir. Araştırmadan elde edilen bu sonuç alanyazında yer alan pek çok araştırma bulgusuyla tutarllık göstermektedir.

Alanyazında özel gereksinimli bireylerin sosyal kabulü üzerine yapılan çalışmalar incelendiğinde, tek bir yetersizlik grubuna yönelik farklı uygulama tekniklerinin bir arada kullanıldığı araştırmalara rastlanmaktadır (Civelek 1990; Çiftçi 1997; Krahe ve Altwasser 2006, s.59-69; Manetti, vd., 2001, s.282-285; Şahbaz 
2004, s.82-92; Westtervelt ve McKinney 1980, s.294296). Bu çalışmada ise bilgilendirme, canlandırma ve tartışma tekniklerinin birlikte kullanıldığı uygulama programı tek bir yetersizlik grubuna yönelik değil farklı yetersizlik gruplarına (görme, işitme, zihinsel, fiziksel) yönelik olarak uygulanmıştır.

Araştırmada deney ve kontrol gruplarının sosyal kabul düzeylerine ilişkin ön-test ve son-test verilerini toplamak amacıyla SKÖ kullanılmıştır. Aynı ölçek ülkemizde Tekin (1994) ve Aktaş (2001) tarafından yapılan çalışmalarda uygulanmıştır. Tekin (1994, s.84-89) çalışmasında yönlendirici ve yönlendirici olmayan akran tartışmasını ön plana çıkaran uygulama tekniklerini kullanmıştır. Bu farklı uygulamaların yanı sıra çalışmada araştırmaya katılan gruplar engelli olimpiyatları filmini seyretmiş ve yetersizliği olan bir avukatın katıldığı oturumlara katılmıştır. Aktaş (2001, s. 87-91) ise çalışmasında bedensel yetersizlik hakkında bilgi verme, özel gereksinimli bireylerle etkileşim kurma ve yetersizliğin canlandırılması gibi bilişsel ve duyuşsal tutum değiştirme yöntemlerini birlikte içerecek biçimde çalışmalar gerçekleştirmiştir. Bu çalıșmanın Aktaş (2001)'ın çalıșmasından farkı, farklı yetersizlik gruplarını kapsamasıdır. Aynı şekilde Tekin (1994)'in çalışmasından farkı ise farklı yetersizlik türleriyle ilișkili canlandırma çalışmalarının yapılmasıdır. Bu bağlamda yapılan çalışmanın alanyazına katkı getireceği düşünülmektedir. Ayrıca bu çalışmanın sözü edilen çalışmalardan farkı, yapılan çalışmada araştırmacılar tarafından hazırlanan “Kaynaştırmaya Hazırlık Etkinlikleri”nin özel gereksinimli bireylere yönelik sosyal kabulü artırmak amacıyla uygulanacak bir paket program niteliğinde olmasıdır. Araştırmacı tarafından geliştirilen "Kaynaştırmaya Hazırlık Etkinlikleri” sırasında kullanılan materyallerin ediniminin son derece pratik ve maliyetinin düşük olması çalışmanın uygulanabilirliğini artırmaktadır.

Yapılan çalışmanın bu uygulanabilirliğinin yanı sıra, belli sinırlılıkları da bulunmaktadır. Kontrol grubu ile etkinliklerin yapılamamış olması en önemli sınırlılık olarak gösterilebilir. Diğer bir sınırlılık ise, deney grubundaki öğrencilerin sosyal kabul düzeyine ilişkin verileri, uygulamanın tamamlanmasından iki gün son sonra alınan son test verileri ile sınırlı olup, okulların tatil olması nedeniyle izleme çalıșmasının yapılamamıș olmasıdır. Bu durum ayrıca çalıșmanın kontrol grubuyla kaynaştırmaya hazırlık etkinliklerinin yapılamamış olmasının da bir gerekçesidir.
Araştırmadan elde edilen bulgular ve sinıllılıklar doğrultusunda ileri araştırmalara yönelik öneriler, kaynaştırmaya hazırlık uygulamaları sonucunda meydana gelen sosyal kabul düzeyinin değişikliğinin kalıcılığını belirlemek amacıyla izleme çalışmaları yapılması, normal gelişim gösteren öğrencilerin özel gereksinimli bireylere yönelik günlük yaşam içerisindeki davranışlarına yansımasını inceleyen gözleme dayalı farklı çalışmalar yapılması olarak sıralanabilir. $\mathrm{Bu}$ önerilere ek olarak, öğrencilerin tutum ve sosyal kabul ölçeklerine verdikleri yanıtlarla davranışları arasındaki tutarlılığı araştıran çalışmaların yapılması ve benzer araştırmalarda sosyal geçerlilik verilerinin annelerin yanı sıra katılımcılar, babalar, ya da uzmanlardan da toplanması gibi farklı çalışmalar planlanması da önerilebilir.

Araştırmadan elde edilen bulgular doğrultusunda uygulamaya yönelik önerilerde ise, araştırmada uygulanan kaynaştırmaya hazırlık etkinlikleri, halen uygulanmakta olan grup rehberliği etkinlikleri içerisinde ek etkinlik olarak eklenebilir ya da farklı bir program olarak kullanımı yaygınlaştırılabilir. Son olarak, araştırmada uygulanan kaynaştırmaya hazırlık etkinliklerinin sınıf öğretmenlerine, sınıfa özel gereksinimli öğrenci gelmeden önce normal gelișim gösteren akranlarla hazırlık çalışması yapabilmesi için kullanımı önerilebilir

\section{Kaynakça}

Akçamete, G. \& Kargın, T. (1994). Hizmet-içi Eğitim Programlarının Öğretmenlerin İşitme Engelli Çocuklara Yönelik Tutumlarına Etkisi. Özel Eğim Dergisi, 1(4), 13-19.

Aktaş, C. (2001). İlköğretim Öğrencilerinin Fiziksel Özürlü Yaşıtlarına Yönelik Sosyal Kabul Düzeylerinin Geliştirilmesi. Ankara: Başbakanlık Özürlüler İdaresi Başkanlığı Yayınları.

Anderson, R. (1992). The Effectiveness of Puberty and Film Modifying Students Perception Towards Person with Disabilities. Dissertation Abstract International,53(11), 3793-A.

Aral, N. \& Dikici, A. (1998). Normal Gelișim Gösteren Çocukların Özel Gereksinimli Olan Akranları Hakkındaki Görüșlerinin İncelenmesi. 8. Ulusal Özel Eğitim Kongresi (13-15 Kasım 1998) bildiriler kitabı içinde (s.49-54). Edirne: Trakya Üniversitesi Yayınları. 
Batu, S. (2008). Kaynaştırma ve Destek Özel Eğitim Hizmetleri, İbrahim. H. Diken (Ed.), Özel Eğitim içinde (s. 91-106). Ankara: Pegem Akademi Yayıncllık.

Batu, S. \& Kurcaali-İftar, G. (2006). Kaynaştırma. Ankara: Kök Yayıncılık.

Batu, E.S., Çolak, A. \& Odluyurt, S. (2012). Özel Gereksinimli Öğrencilerin Kaynaştırılması. Ankara: Vize Yayıncilık.

Büyüköztürk, Ş., Kılıç-Çakmak, E., Erkan Akgün, Ö., Karadeniz, Ş. \& Demirel, F. (2008). Bilimsel Araştırma Yöntemleri. Ankara: Pegem Akademi.

Canküyer, E. \& Aşan, Z. (2005). Parametrik Olmayan İstatistiksel Teknikler. Eskişehir: Anadolu Üniversitesi Yayınları.

Civelek, A. H. (1990). Eğitilebilir Zihinsel Özürlü Çocuklarm Sosyal Kabul Görmelerinde Normal Çocuklarm Bilgilendirilmelerinin ve İki Grubun Resim-İş ile Beden Eğitimi Derslerinde Bütünleştirilmelerinin Etkileri. (Yayımlanmamış doktora tezi). Ankara: Ankara Üniversitesi/Sosyal Bilimler Enstitüsü, Ankara.

Çifçi, İ. (1997). Normal Çocukları Bilgilendirmenin Zihinsel Engelli Yaşıtlarına Yönelik Tutumlarına Etkisi. (Yayımlanmamış yüksek lisans tezi). Bolu: Abant İzzet Baysal Üniversitesi/Sosyal Bilimler Enstitüsü, Bolu.

Diler, N. (1998). Kaynaştırma Kavramı Kaynaştırma Uygulamaları ve Etkili Kaynaştırma İçin Yapılması Gerekenler. 8. Ulusal Özel Ĕ̆itim Kongresi (13-15 Kasım 1998) bildiriler kitabı içinde (s. 157-162). Edirne: Trakya Üniversitesi Yayınları.

Donaldson, J. (1980). Changing Attitudes towards Handicapped Person: A Review and Analysis of Research. Exceptional Children, 46(7), 504-514.

Eratay, E. ve Sazak-Pınar, E. (2006). Genel Eğitim Sınıflarındaki Zihin Engelli Öğrencilerin Arkadaşlık İlişkilerinin İncelenmesi. Abant İzzet Baysal Üniversitesi Sosyal Bilimler Enstitüsü Dergisi, 2(13), 24-47.
Erbaş; D. (2012). Güvenirlik. Elif Tekin-İftar (Ed.), Eğitim ve Davranış Bilimlerinde Tek Denekli Araştırmalar içinde (s. 109-133). Ankara: Türk Psikologlar Derneği Yayınları.

Ferguson, G.A. (1981). Statistical Analysis in Psychology and Education (5. Baskı). Auckland: McGraw Hill.

Gay, L.R., Mills, G.E. ve Airasian, P. (2006). Educational Research Competencies for Analysis and Applications. New Jersey: Pearson.

Ibrahim, F.A. (1982). Modification of Attitudes towards Disability: Differential Effect of Two Educational Model. Rehabilitation Counseling Bulletin, 29-36.

Kennedy, C.H. (2005). Single Case Designs for Educational Research. USA: Pearsson.

Kurt, O. (2012). Sosyal Geçerlik. Elif Tekin-İftar, (Ed.), Eğitim ve Davranış Bilimlerinde Tek Denekli Araştırmalar içinde (s: 375-394). Ankara: Türk Psikologlar Derneği Yayınları.

Küçüker, S. (1997). Bilgi Verici Psikolojik Danışmanlık Programının Zihinsel Özürlü Çocukların Kardeşlerinin Özürlülerle İlgili Bilgi Düzeylerine ve Özürlü Kardeşlerine Yönelik Tutumlarına Etkisi. (Yayımlanmamış doktora tezi). Ankara Üniversitesi/Sosyal Bilimler Enstitüsü, Ankara.

Küçüker, S. \& Rihter-Kanık, N. (1994). Normal Çocuğa Sahip Anne Babaların Özürlü Çocuklara Yönelik Tutumları. Özel Ĕgitim Dergisi, 1(4), 20-28.

Krahe, B. \& Altwasser, C. (2006). Changing Negative Attitudes towards Person with Physical Disabilities. Journal of Community and Applied Social Psychology, 16, 59-69.

Leyser, Y., Cumblad, C. \& Strikman, D. (1986). Direct Intervention to Modify Attitude towards the Handicapped by Community Volunteers: The Learning About Handicapped Programme. Educational Review, 38(3), 229-236.

Manetti, M., Schneider, B. H. \& Siperstein, G. (2001). Social Acceptance of Children with Mental Retardation: Testing the Contact Hypothesis with an Italian Sample. International Journal of Behavioral Development, 25(3), 279-286. 
McGowan, P.C. (1999). The Effect of Simulation on Attitudes Towards Person With Disabilities. (Yayınlanmamış doktora tezi). Seto Hall University. USA.

Siperstein, G.N. (1980). Instruments for Measuring Children's Attitudes Toward the Handicapped. (Unpublished manuscript). Boston: University of Massachusets.

Sucuoğlu, B. \& Kargın, T. (2006). Kaynaştırma Uygulamaları. Ankara: Morpa Yayınları.

Şahbaz, Ü. (2004). Kaynaştırma Sınıflarına Devam Eden Zihin Engelli Öğrencilerin Sosyal Kabul Düzeylerinin Belirlenmesi. 13. Ulusal Özel Eğitim Kongresi (12-14 Kasım 2004) bildiriler kitabı içinde (s.82-92). Eskişehir: Anadolu Üniversitesi Yayınları.

Şahbaz, Ü. (2007). Normal Öğrencilerin Kaynaştırma Sınıflarına Devam Eden Engelli Öğrenciler Hakkında Bilgilendirilmelerinin Engellilerin Sosyal Kabul Düzeylerine Etkisi. Eurasian Journal of Educational Research. 26, 199-208.

Tekin, E. (1994). The Effects of Exposure to Information Techniques on Fourth Grade Children's Social Acceptance Level of Exceptionality. (Yayımlanmamıș yüksek lisans tezi). Orta Doğu Teknik Üniversitesi/ Sosyal Bilimler Enstitüsü, Ankara.

Turhan, C. (2007). Kaynaştırma Uygulaması Yapılan İlköğretim Okuluna Devam Eden Normal Gelişim Gösteren Öğrencilerin Kaynaştırma Uygulamasına İlişkin Görüşleri. (Yayımlanmamış yüksek lisans tezi). Anadolu Üniversitesi/ Eğitim Bilimleri Enstitüsü, Eskişehir.

Vuran, S. (2005). The Sociometric Status of Students with Disabilities In Elementary Level Integration Classes in Turkey. Eurasian Journal of Educational Research, 18, 217-235.

Westervelt, V. D., \& McKinney, J. D. (1980). Effects of A Film on Non-handicapped Children's Attitudes toward Handicapped Children. Exceptional Children, 46(4), 294-296.

\section{EK 1}

ETKİNLİĞİN ADI: Benim İçin Zor

\section{ETKİNLİĞIN AMACI:}

- Normal gelişim gösteren öğrencilerin, zihin yetersizliği ya da öğrenme güçlügü olan bireylerin günlük yaşamda karşılaştıkları olaylar karşısında neler hissedebilecekleri konusunda duyarlılık kazanmalarını sağlamak.

- Normal gelişim gösteren öğrencilerin zihin yetersizliği ya da öğrenme güçlüğü olan bireylerin günlük yaşamda karşılaştıkları güçlüklerin ortadan kaldırılması için neler yapabilecekleriyle ile ilgili düşünce üretmelerini sağlamak.

- Normal gelişim gösteren öğrencilerin grup içerisinde yapılan etkinliklerle ilgili duygu ve düşüncelerin paylaşımını sağlamak.

DÜZEY: İlköğretim 3., 4. ve 5. sinıflar

MATERYALLER: İngilizce hikaye kitabı, kaset, kasetçalar.

SÜRE: 40 dakika.

\section{Uygulama Süreci}

\section{Etkinlikle İlgili Bilgilendirme Yapma:}

Uygulamacı konuyla ilgili giriş yapar ve öğrencilerin dikkatlerini konuya çeker. Ardından, ders sırasında vereceği yönergeleri tüm öğrencilerin yerine getirmesini ister.

\section{Etkinlikle İlgili Alıştırmalar Yapma:}

- Öğretmen tahtaya ileri matematik işlemlerini içeren bir problem yazar ve "Kimse birbirine herhangi bir şey sormadan bu problemi 5 dakika içerisinde defterine çözsün." diyerek yönerge verir.

- Beş dakika sonra öğretmen öğrencilere sıradaki etkinliğe geçeceklerini ve bu çalışmanın süresinin dolduğunu söyler. 
- Uygulamacı sıradaki etkinliğin hikaye okuma çalışması olduğunu, bunun için sınıfa bir misafirin geleceğini ve onlara hikaye okuyacağını söyler.

- Uygulamacı okulun İngilizce öğretmenini sınıfa çağırır ve öğrencilere bilmedikleri kelimelerden oluşan bir hikayeyi hızlıca okumasını ister.

- Hikaye okunduktan sonra uygulamacı öğrencilere İngilizce hikaye ile ilgili sorular sorar ve cevaplamalarını ister.

- Uygulamacı tarihsel bir olayın anlatıldığı konuşmayı öğrencilere kasetten hızlandırılmış ayarda dinletir ve anlatılanları yazmalarını ister.

Yukarıda sıralan çalışmalar tamamlandıktan sonra uygulamacı aşağıdaki soruları öğrencilere yönelterek, öğrencilerin seviyelerinin üzerinde bir durumla karşılaştıklarında içinde bulundukları durumu fark etmelerini sağlar.

- Daha önce hiç görmediğiniz işaret ve sembolleri içeren problemi çözmeniz istendiğinde neler hissettiniz?

- Bu problemle karşılaştığınızda ne tür yardımlara ihtiyaç duydunuz?

- Daha önce hiç duymadığınız İngilizce kelimelerin olduğu hikaye okunurken neler hissettiniz?
- Bu hikayeyi anlayabilmek için neler yapılmasını isterdiniz?

- Kasetten hızlandırılarak dinletilen olayı yazmaya çalışırken neler hissettiniz?

- Anlatılanları yazabilmek için neler yapılmasını isterdiniz?

\section{Etkinliğin Değerlendirilmesi:}

Uygulamac1, "Çocuklar gördüğünüz gibi bugün yaptığımız bu üç etkinlikte de yapmanızı istediğim şeyler sizlere çok zor geldi. Hatta yapamadınız. İlk çalışmamızdaki problemi çok rahatlıkla yapabilen kişiler var, anlatılan hikayeyi çok iyi anlayabilen kişiler var. Fakat bu üç etkinliği anlamak bize çok zor geldi. İşte başka insanlara kolay gelen bu tür konular, bizlere zor gelebilir ve anlamakta zorlanabiliriz. Aynı şekilde, bizim için kolay olan, bildiğimiz, öğrendiğimiz şeyleri öğrenemeyen, onlara zor gelen arkadaşlarımız olabilir. $\mathrm{Bu}$ arkadaşlarımız daha önce bahsettiğimiz zihinsel engelli ya da öğrenme güçlüğü tanısı olabilirler ve bizim kolaylıkla öğrendiğimiz bazı şeyleri öğrenmekte zorluk çekebilirler. Bu arkadaşlarımız, bizlerin yardımına ve desteğine ihtiyaç duyabilirler. Bu arkadaşlarımızla iletişim kurarken, bugün yaşadığınız zorlukları unutmayın ve kendinizi onların yerine koyarak onlara yardımcı olmaya çalışın." diyerek etkinliği sonlandirır. 